\title{
1986 Alaska fieldwork, Lisburne Peninsula and western De Long Mountains, Alaska
}

Krass, V.A., Vaitl, J.D., and Amoco Oil Co.

GMC DATA REPORT 459

This GMC data report from the Amoco Heritage collection has been made available through funding from the FY2018 USGS National Geological and Geophysical Data Preservation Program, Grant Number G18AP00054. This project report is presented in its original format and has not been reviewed for technical content or for conformity to the editorial standards of DGGS. It should not be used or cited as reviewed data.

2019

State of Alaska

Department of Natural Resources

Division of Geological \& Geophysical Surveys

GEOLOGIC MATERIALS CENTER
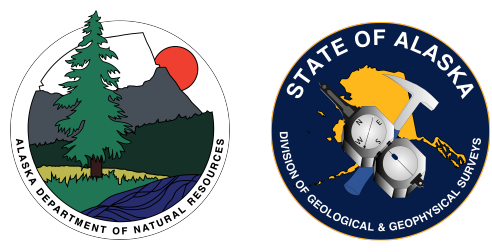


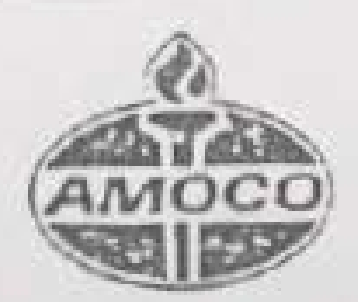

\section{Amoco Production Company \\ Denver Region \\ Northern Division}

AREA Lisburne Peninsula and Western De Long Mountains

STATE Alaska

COUNTY

SUBJECl 1986 Fieldwork, Lisburne Peninsula and Western De Long Vountains, Alaska

Geological Report: No. $\mathrm{NO}-14-86 \mathrm{R}$

Dale Auqust. 1986

BY V.A. Krass, J.D. Vaitl

1

2

$\underline{3}$

$\frac{4}{5}$

$\frac{6}{7}$

$\frac{8}{9}$

$\frac{10}{11}$

12

13

14.

15

16.

17

18

19

-31

$\frac{22}{23}$

$\frac{24}{25}$

Lisburne Bi11s stratigraphic column

West Brooks Range Allochthon

West Brooks Range Palinspastic Reconstruction

Geologie Map Showing Prior Field Work Measured Section Locationg"

Geophoto Map of Lisburne Peninsula

West Brooks Range Cross Section

West Brooks Range Restored Cross Section and Plate 81 story

Point Hope Quad $1: 250,000$

De Long Mountains Quad 1:250,000

Noutak Quad 1:250,000

Point Hope (A1) $1: 63,360$

Paint Hope (B1) 1:63, 360

Point Hope (B2) $1: 63,36 \mathrm{C}$

Point lone (B3) $1: 63,360$

Point Hope (Cl) $1: 63,360$

point Hope (C2) 1:63, 360

Point Hope (C3) $1: 63,360$

point Hape (D) 1.6.3, 369

Point Hope (D2) $1: 63,360$

De fong Mountains (A2) $1: 63,360$

De Long Mountains (B3) 1:63,360

De Long Mountains (B4) $1: 63,360$

Noatak (D7) $1: 63,360$

Noatak (D6) $1: 63,360$ 


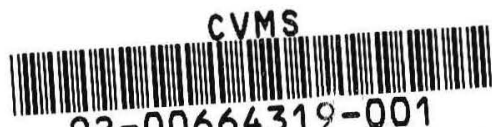

K. F. Arleth

$2002 A B$

Transmittal of Geological Report

NO-14-86R, 1986 Fieldwork,

Lisburne Peninsula and Western DeLong Mountains, Alaska

This report by Valerie Krass and Jon Vaitl documents geological field work undertaken in 1986 in preparation for Chukchi ocs Sale 109. Results of this fieldwork were incorporated into stratigraphic and geochemical models developed for the sale evaluation.

轮及

A. E. Berman

$\mathrm{AEB} / \mathrm{slm}$

CC: R. J. Shafer

Authorized for Transmittal:

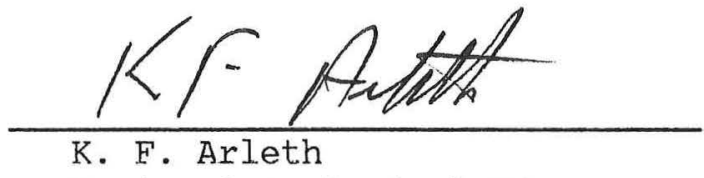

Regional Geological Manager 
August, 1986

Denver Region Northern

Division Geological Report

1986 Alaska Field Work:

Lisburne Peninsula and

Western De Long Mountains

Part I: Preliminary Investigation

\section{INTRODUCTION}

CONCLUSIONS

RECOMIMENDATIONS

ENCLOSURES

\section{FIGURES}

\section{REFERENCES}

\section{DISCUSS ION}

Regional Geologic setting

Previous Work

1986 Field Work

Lisburne Peninsula Stratigraphy

Lower Cretaceous

Jurassic to Lower Cretaceous Ipewik Formation

Permo-Triassic Otuk/Siksikpuk Formations

Pennsylvanian Section

Upper Mississippian Lisburne Group

Lower Mississippian Endicott Formation

Silurian/Ordovician Iviagik Group

Western De Long Mountains Stratigraphy

Lower Cretaceous Opikruak Formation

Jurassic to Lower Cretaceous Ipewik Formation

Pennsylvanian-Jurassic otuk/Siksikpuk Formations

Potential Reservoir Facies

Potential Source Rock Facies

Sample Analysis Schedule

Field Conditions and Logistical support

Tectosat Program

Industry Surveillance

\section{APPENDI CES}

I. Field Notes

II. Permit File (Denver Only)

III. Sample Registers

IV. Photo Log (Denver only)

V. Government and Native Report Compliance

VI. Helicopter Contract

VII. Inventory of Available 1969 Field Party Samples

Authors :

V. A. Krass

J. D. Vaitl

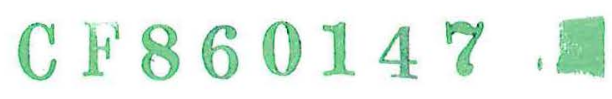


This report documents the data gathered and geological accomplishments made during the 1986 Amoco field program in the Lisburne Peninsula-western De Long Mountains area of northwestern Alaska. The primary purpose of the field season was to examine the western Brooks Range outcrop belt in closest proximity to the Chukchi sea in support of the upcoming offshore sales, OCS 109 and OCS 97. Rock data on reservoir and source potential for the Chukchi sea area is limited to sparse well control in the northwestern NPRA (see Figure 1). Facies information from the western Brooks Range provides additional control for reconstruction of the Devonian to early cretaceous sedimentary basin, which is thought to contain the primary petroleum potential for the chukchi sea. Field work was conducted over a nine day period from July 16 to July 24, 1986. Amoco's field crew was led by Valerie Krass and assisted by Jon Vaitl and F. X. O'Keefe. The report is divided into two parts: Part I: Preliminary Investigation, summarizes stratigraphic and structural field observations and logistical data; Part II: Analytical Results, details the paleontology, source rock and reservoir rock analyses and interpretations and will be prepared as results become available.

The goals of the 1986 field party included:

1. Definition of the source rock potential of the late Paleozoic and Mesozoic marine shale sections.

2. Definition of the reservoir potential of the early Mississippian Lisburne dolomite and early Cretaceous turbidite sandstones.

3. Paleontological sampling to determine the presence of Jurassic and Neocomian rocks for interpretation of the regional extent of the Kingak and Pebble shale source rock intervals.

4. Examination of the sedimentary facies of the silurianOrdovician, early Mississippian Endicott, Permo-Triassic and early cretaceous to develop a better understanding of their depositional history. Utilize the data obtained to aid in regional paleogeographic reconstructions and prediction of source/reservoir trends for the western North slope and Chukchi Sea.

5. General structural observations to define the structural style, timing of deformational events and relationship between the dominant north-south structural grain of the Lisburne Peninsula and the regional east-west structural grain of the Brooks Range.

\section{CONCLUSIONS}

1. The Franklinian Iviagik formation, exposed on the Lisburne Peninsula, is a silurian/Ordovician mildly metamorphosed distal marine turbidite graywacke sequence. The Iviagik was deposited from a rapidly eroding highland presumably related to an early paleozoic subductive margin. These rocks correlate in age and lithology with the regional Franklinian "Argillite" of the North Slope.

2. The Ellesmerian sequence includes nonmarine to marginal marine clastics of the Endicott Group, carbonates of 


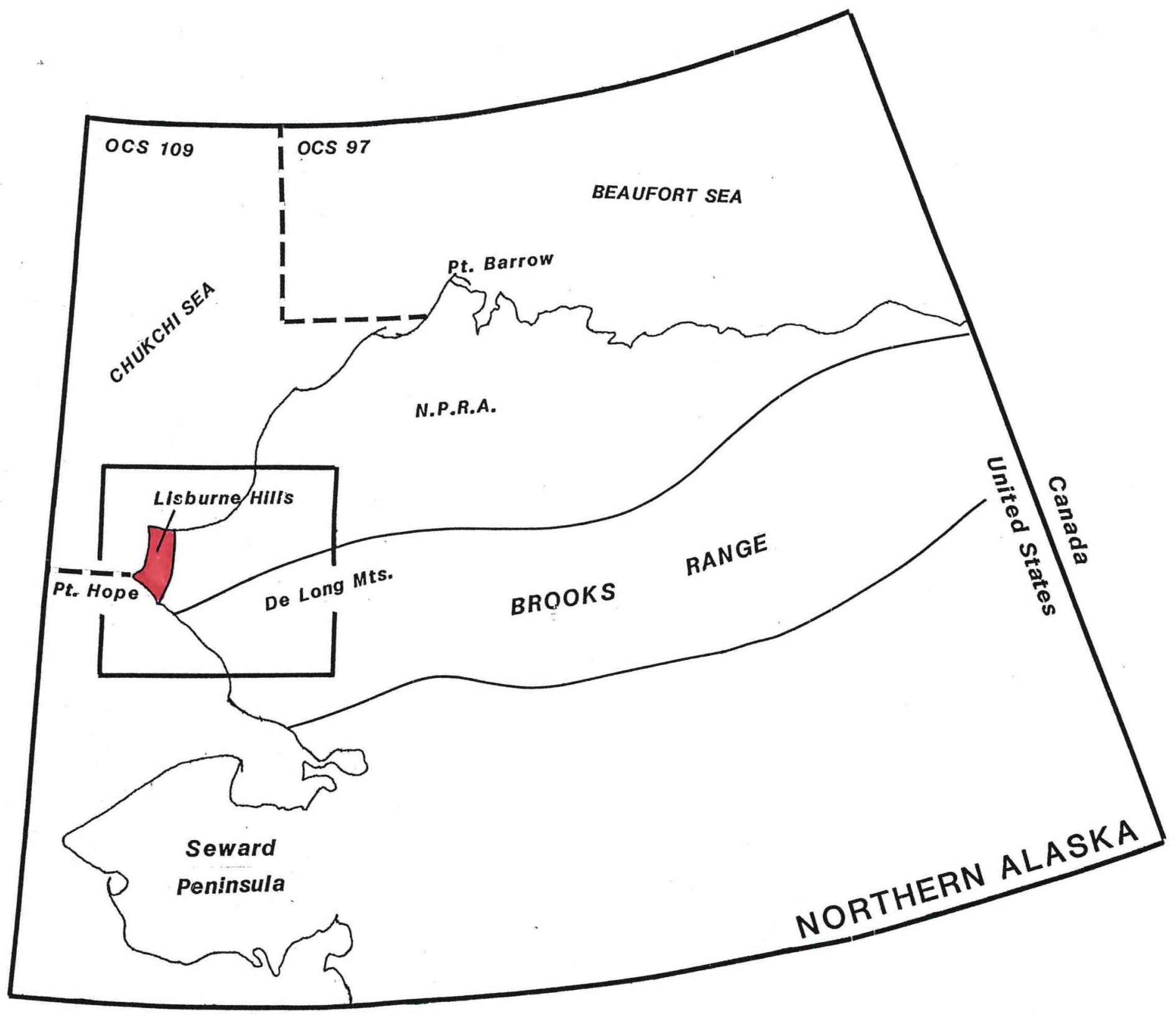

map of northern Alaska showing 1986 field work area in red. 
the Lisburne Group, and basinal siliceous shale and chert of the Etivluk Group and Ipewik formation. The Lisburne section contains thick dolomite, bioclastic limestone and local coralline bioherms, all of which have little to no porosity in outcrop. The Etivluk Group black shale and chert facies represents a distal marine equivalent to the Permo-Triassic Sadlerochit Group, and the Jurassic Ipewik formation black shale represents a southern equivalent to the Pebble shale. It is expected geochemical analysis will confirm these units as good to excellent oil sources.

3. Brookian rocks are represented by thick turbidites of the Okpikruak, Ogotoruk, Telavirik, Kisimolik and Fortress Mountain formations, which were deposited northward in front of a rising Brooks Range during the Brookian Orogeny. Examination of the age of the basal units within the turbidite section demonstrates a northward-prograding flysch sequence deposited from middle Jurassic to early Cretaceous time. This thick, shale-rich section is expected to be primarily gasprone based on the dominance of plant fossils.

4. Analysis of samples collected from potential oil-generating facies (Permo-Triassic Etivluk and Jurassic Ipewik) and gas-generating facies (Mississippian Endicott and Cretaceous turbidite sequences) will be integrated into palinspastic reconstruction of the Ellesmerian and Brookian depositional basins. This will provide a constrained framework for SUBSIDE modelling of the western North slope hydrocarbon generating potential.

5. On the basis of field observation, the reservoir potential of allochthonous Ellesmerian rocks is very poor. No visual porosity was seen in any part of the section. Samples were collected for reservoir analysis to confirm this observation.

6. Thrust transport direction in the Lisburne Hills was from west to east which is perpendicular to the structural grain of the Brooks Range. It is unlikely that the Lisburne thrusts are simple klippe of the Brooks Range thrust as is implied by Mayfield, C. F., et al., (1983).

\section{RECONIMENDATIONS}

1. Source rock data obtained through the 1986 field program should be integrated into the regional data set to provide additional constraints on source character of Ellesmerian sediments buried under the Colville Trough.

2. Paleogeographic palinspastic reconstruction of Ellesmerian facies should be made using the western Brooks Range USGS detailed mapping. Information contained in these reports should be reviewed for regional basin analysis implications and future field work alternatives.

\section{ENCLOSURES}

1. Lisburne Hills stratigraphic Column

2. West Brooks Range Allochthon Map 
3. West Brooks Range Palinspastic Reconstruction

4. Geologic Map Showing Prior Field Work Measured Section Locations

5. Geophoto Map of Lisburne Peninsula

6. West Brooks Range Cross Sections

7. West Brooks Range Restored Cross Section and Plate History

8. Point Hope Quad 1:250,000

9. De Long Mountains Quad 1:250,000

10. Noatak Quad 1:250,000 (Denver only)

11. Point Hope (A1) $1: 63,360$ (Denver only)

12. Point Hope (B1) 1:63,360 (Denver only)

13. Point Hope (B2) $1: 63,360$ (Denver only)

14. Point Hope (B3) 1:63,360 (Denver only)

15. Point Hope (C1) 1:63,360 (Denver only)

16. Point Hope (C2) $1: 63,360$ (Denver only)

17. Point Hope (C3) 1:63,360 (Denver only)

18. Point Hope (D1) 1:63,360 (Denver only)

19. Point Hope (D2) 1:63,360 (Denver only)

20. De Long Mountains (A3) $1: 63,360$ (Denver only)

21. De Long Mountains (A4) 1:63,360 (Denver only)

22. De Long Mountains (B3) 1:63,360 (Denver only)

23. De Long Mountains (B4) 1:63,360 (Denver only)

24. Noatak (D7) 1:63,360 (Denver only)

25. Noatak (D6) $1: 63,360$ (Denver only)

\section{FIGURES}

1. Index Map of Northern Alaska

\section{REFERENCES}

Armstrong, A. K. and B. L. Mamet, 1977, Carboniferous Microfacies, Microfossils, and Corals, Lisburne Group, Arctic Alaska: USGS Prof., Pp. 849.

Barnes, F. F., 1967, Coal Resources of the Cape LisburneColville River Region, Alaska: USGS Bulletin 1242-E. 
Campbell, R. H., 1967, Areal Geology in the Vicinity of the Chariot Site, Lisburne Peninsula, Northwestern Alaska: USGS Prof., Pp. 395.

Chauvel, J. P., 1969, Geological Reconnaissance 1969, Western Brooks Range, Alaska: Amoco Denver Geological Report No. CF690006 (Chevron).

Collier, A. J., 1906, Geology and Coal Resources of the Cape Lisburne Region, Alaska: USGS Bulletin 278.

Curtis, S. M., I. Ellersieck, C. F. Mayfield, and I. L. Tailleur, 1982, Reconnaissance Geologic Map of Southwestern Misheguk Mountain Quadrangle, Alaska: USGS Open-File Report No. 82-611.

Curtis, S. M., I. Ellersieck, C. F. Mayfield, and I. L. Tailleur, 1983, Reconnaissance Geologic Map of the De Long Mountains A1, B1 and Part of C1 Quadrangles, Alaska: USGS Open-File Report No. 83-185.

De Benedetti, J. J., R. Rose, and D. W. Abrahamson, 1971, Semi-detail Reconnaissance of the Western Brooks Range, Northern Alaska: Amoco Denver Geological Report

No. CF710035.

Ellersieck, I., S. M. Curtis, C. F. Mayfield, and I. L. Tailleur, 1982, Reconnaissance Geologic Map of South-Central Misheguk Mountain Quadrangle, Alaska: USGS Open-File Report No. 82-612.

Ellersieck, I., S. M. Curtis, C. F. Mayfield and I. L. Tailleur, 1983, Reconnaissance Geologic Map of the De Long Mountains A2, B2, and Part of C2 Quadrangles, Alaska: USGS Open-File Report No. 83-184.

Fehlman, R. H., 1970, Data Compilation of the 1970 Amoco Field Party, Western and Central Brooks Range, Alaska: Amoco Denver Geological Report No. CF710036.

Grantz, A., I. L. Tailleur and C. Carter, 1983, Tectonic Significance of Silurian and Ordovician Graptolites, Lisburne Hills, Northwest Alaska (abs.): Geol. Soc. Am. Abstracts With Prog., v. 15, no. 5, p. 274.

Knapp, W. D. and W. M. Dalness, 1970, Progress Report on the Surface Geology of the Western Brooks Range, Alaska: Amoco Denver Geological Report No. CF700018.

Martin, A. J., 1970, Structure and Tectonic History of the Western Brooks Range, De Long Mountains and Lisburne Hills, Northern Alaska: Geol. Soc. Am. Bulletin, v. 81, no. 12, pp. 3605-3622.

Mayfield, C. F., S. M. Curtis, I. Ellersieck, and I. L. Tailleur, 1982, Reconnaissance Geologic Map of the Southeastern Part of the Misheguk Mountain Quadrangle, Alaska: USGS open-File Report No. 82-613.

Mayfield, C. F., S. M. Curtis, I. Ellersieck and I. L. Tailleur, 1983, Reconnaissance Geologic Map of the De Long Mountains A3, B3, and Parts of A4, B4 Quadrangles, Alaska: USGS Open-File Report No. 83-183.

Mayfield, C. F., I. L. Tailleur and I. "Ellersieck, 1983, Stratigraphy, Structure and Palinspastic Synthesis of the Western Brooks Range, Northwestern Alaska: USGS Open-File Report No. 83-779. 


\section{DISCUSSION}

\section{Regional Geologic Setting}

The Lisburne Hills and De Long Mountains lie in the extreme western portion of the Brooks Range Province of the North Slope of Alaska (Figure 1). This part of the Brooks Range is underlain by a thick sequence of structurally disturbed rocks which range in age from ordovician to early cretaceous (see Enclosure 1 for stratigraphic section exposed in Lisburne Hills). The section can be divided into three regional depositional packages.

Basement rocks for the area, exposed along the west coast of the Lisburne Peninsula, consist of mildly metamorphosed Ordovician and Silurian graywackes and slates of the Franklinian sequence.

These rocks are unconformably overlain by carbonate and clastic sediments of the Ellesmerian sequence, which was deposited in a stable continental margin setting from late Devonian to late Jurassic/early Cretaceous time. Rocks in the group include the Devonian to early Mississippian Endicott nonmarine to marginal marine clastics, Mississippian to Pennsylvanian Lisburne platform carbonates and PermoTriassic and Jurassic distal marine shales and cherts, with sediment input dominantly from the north.

The Brookian Orogeny, which began in the late Jurassic, created a rising sediment source in the south and resulted in deposition of the Brookian sequence. A thick turbidite section (Opikruak, Ogotoruk, Te lavirak, Kisimolok, Fortress Mountain formations), later succeeded by deltaic clastics (the Nanushuk and Colville Groups), was deposited across the Brooks Range and northward into the growing foredeep of the Colville Trough. The compressional deformation associated with the Brookian Orogeny juxtaposed these rocks into a series of stacked thrust sheets which were later gently folded and eroded to form numerous klippen and fensters (see Enclosure 2, Western Brooks Range Allochthons). Thus, the Ellesmerian continental margin sediments presently exposed in the western Brooks Range are allochthonous with respect to the North slope, and represent facies originally deposited further to the south (see Enclosure 3, Palinspastic Reconstruction). The Lisburne Peninsula and De Long Mountains are thought to belong to the structurally lowest thrust plate and have, therefore, moved the least with respect to the autochthonous Ellesmerian section which underlies the chukchi sea and NPRA. The dominant structural grain of the western Brooks Range thrusts documents south to north compression, with total shortening estimated at more than $800 \mathrm{~km}$ (Mayfield and others, 1983). In the Lisburne Hills area, the Cretaceous to Tertiary structures have north-south trends and appear to have moved, by at least a small amount, from west to east, as well as an uncertain distance from south to north (Mayfield and others, $1983)$.

\section{Previous Work}

During 1969, 1970 and 1971, Amoco and joint Amoco-Union field parties made preliminary investigations of the Lisburne Peninsula area as part of their studies on the geology of the western Brooks Range (CF700420, CF710036, CF710035). A UnionGulf field report from 1969, also on the western Brooks Range, was acquired by a partnership agreement with Union, and is filed in the Denver vault as CF690006. The primary focus of 
each of these studies was regional stratigraphy, and each party spent only a short period of time working in the Lisburne Peninsula area. A number of sections were measured in these three seasons along the western and southern coasts:

\author{
Endicott Group: \\ Lisburne Group:
}

Angolik Creek-Cape Dyer

\author{
Niak Creek \\ Nasorak Creek \\ Cape Lewis \\ Cape Thompson
}

Shublik (Otuk)/Siksikpuk: Agate Rock

A composite map, Enclosure 4, shows locations of both industry and academic measured sections and prior mapping in the Lisburne Hills area. Many other sections were measured further to the east in the De Long and Baird Mountains, focusing on the Lisburne and Baird Group carbonate systems. The 1969-1971 field parties recognized the difficulty in putting together a regional depositional picture in the main part of the western Brooks Range due to the complexity of the structure, and recommended that structural studies be initiated.

The Amoco work from the late sixties and early seventies provides a good descriptive basis for study, but little analytical data was found on source rock (only three or four useful analyses) or reservoir rock. A search for archived samples turned up mostly acidized residue remains from the carbonate sections, some cherts and siliceous mudstones and very little shale (see Appendix VII for a partial listing of 1969-1971 samples archived in Tulsa).

The USGS has provided the bulk of the published work in the western Brooks Range and Lisburne Peninsula. In 1906, Collier described a Mississippian through Cretaceous section of largely marine strata, with age assignments based on sparse megafossil control and correlations with regional stratigraphy. On the Lisburne Peninsula, the first detailed geological mapping was done in 1958-1960 in support of the Atomic Energy Commission's Project Chariot, a proposed nuclear test excavation. This work, reported in Campbell (1967), produced a detailed map of 350 square miles of the southern half of the Lisburne Hills and included numerous measured sections of the early Mississippian to early Cretaceous. In Armstrong and Mamet (1977), detailed measured sections of the Lisburne Group at Cape Lisburne, Cape Lewis and Cape Thompson were incorporated into a regional North Slope study of the Lisburne carbonates. They documented the presence of primarily late Mississippian Lisburne, correlative with the Alapah formation, and thick sections of dolomite. Barnes (1967) did additional work on the coal resources of the early Cretaceous Nanushuk Group and the Mississippian Endicott Group. A preliminary report on the structure and tectonic history of the western Brooks Range and Lisburne area was made by Martin (1970). The general timing of Brookian thrusting and folding was constrained as post Fortress Mountain time, and the Lisburne Hills northsouth trending thrust plates were related to regional gravity sliding from the "Tigara" uplift to the west. The only other mapping of the Lisburne Hills was purchased from Geophoto (1970), which extrapolated Campbell's detail of the southern half of the area by air photo interpretation across the rest of the Peninsula (Enclosure 5).

More recent work by the USGS has refined the stratigraphy on the Lisburne Peninsula. Grantz, Tailleur and Carter (1983) 
have documented the presence of a thick silurian-Ordovician section, dated by graptolites, which unconformably underlies the coal-bearing early Mississippian Endicott deposits.

These rocks, named the Iviagik Group by Martin (1970), are described as weakly metamorphosed graywacke, slate and mudstone turbidite deposits and appear correlative with the regional silurian-ordovician argilite package penetrated in numerous wells across the North Slope. Mayfield, Tailleur and Ellersieck (1983) do not discuss the Lisburne Hills area in any detail, but show a stratigraphic column which includes thin Pennsylvanian (?) and Jurassic black shales previously undocumented in the area. No descriptions, paleontologic information or locations are given for these rocks.

Further east, in the De Long and Misheguk Mountain Quadrangle areas of the western Brooks Range, detailed geological mapping has recently been completed. This work defines seven major thrust sheets and attempts palinspastic restoration of the Devonian to Cretaceous section through detailed stratigraphic and structural analysis. This western Brooks Range study is summarized in Mayfield, Tailleur, and Ellersieck (1983) and the mapping documented in several open-file reports including Curtis, Ellersieck, Mayfield and Tailleur (82-611, 83-185), Mayfield, Curtis, Ellersieck and Tailleur (82-613, 83-183) and Ellersieck, Curtis, Mayfield and Tailleur (82-612, 83-184). The Lisburne Hills area is considered to be part of Allochthon One, the thrust sheet which was depositionally closest to the North slope autochthon and has moved the least with respect to it. Mayfield and others (1983) work is included as Enclosures 2, 3, 4, 6 and 7 .

\section{Field Work}

\section{Lisburne Peninsula Stratigraphy}

\section{Lower Cretaceous}

The Lower Cretaceous section on Cape Lisburne consists of a thick ( $\approx 10,000$ feet) graywacke flysch sequence of mudstones, siltstones and sandstones which were deposited as turbidites in a rapidly subsiding basin north of the developing Brooks Range orogenic belt. The overall stratigraphic succession reflects a change through time from distal to proximal turbidite deposition and finally fluvial-deltaic deposition as the basin filled.

The subdivision of this sequence into mappable formations was based primarily on the relative abundance of sandstone and shale. There does not appear to be any major depositional breaks in this stratigraphic succession. The subdivided formations, from oldest to youngest, are the ogotorok, Telavirak, Kisimilok, Fortress Mountain, and Nanushuk. Detailed lithologic and stratigraphic descriptions of these units can be found in Campbell, 1967 and Molenaar, C. M., 1981.

During the 1986 field program, several samples from the Lower Cretaceous sequence were collected for source rock study. The results of these analyses are not yet available but will be presented in Part II of this report. In the Cape Lisburne area, exposures of the Lower Cretaceous are generally poor with only isolated outcrops within stream cuts. An exception is the excellent exposure along the sea cliffs on the north side of the Cape. Here, the structural complexity within this sequence is readily apparent. (See Enclosure 8, stops 7-20-1, 7-20-7, 7-20-8, T7S-R55-59W.) 


\section{Jurassic to Lower Cretaceous Ipewik Formation}

Mayfield, Tailleur and Ellersieck (1983) show a stratigraphic column for the Lisburne Hills sequence which contains two units of Jurassic age (see Enclosure 1). The otuk formation is shown as Triassic (Shublik equivalent) with the uppermost part of the unit, a limestone and shale sequence, ranging into the Jurassic. These rocks are conformably overlain by a thin Jurassic shale, the Ipewik formation (?), which is in turn disconformably overlain by the early cretaceous turbidite sequence, the ogotoruk formation. The disconformity at the top of the Ipewik represents the end of Ellesmerian deposition, as does the Lower Cretaceous Prudhoe Bay Unconformity farther north on the North Slope. No specific paleontologic information for the Jurassic age assignment of the Ipewik is provided and no mapping or location information published. Previous publications on Lisburne Peninsula geology did not recognize or map any Jurassic rocks. In the De Long Mountains to the east, published fossil evidence shows that the type Ipewik is as young as Neocomian (Ellersieck, Curtis, Mayfield and Tailleur, 1983). The regional reconstructions for the western Brooks Range presented by Mayfield and others (1983) depositionally equate the Ipewik shale with the Pebble shale and possibly the uppermost Kingak Shale to the north (Enclosure 7). This correlation suggests analysis of the Ipewik in the Lisburne Hills area may provide regional source rock character information for the Jurassic or Neocomian section of the Chukchi Sea, as the Kingak and Pebble Shales are known to contribute to the oil accumulations across the North slope. Rocks near the contact between the otuk and Ogotoruk were sampled in an attempt to collect part of the Jurassic and possibly Neocomian basinal marine shale section for age control and source rock analysis.

\section{Permo-Triassic Otuk/Siksikpuk Formations}

The otuk (or Shublik) and Siksikpuk formations, joined into the Etivluk Group by Mayfield and others (1983), are well exposed along the south coast of the Lisburne Peninsula at Agate Rock ( $T 32 \mathrm{~N}-\mathrm{R} 32 \mathrm{~W}$ ) and in a deeply dissected stream cut east of Mount Hamlet $(13,18-T 8 S-R 59 W)$. The name otuk formation has been adopted by the USGS for rocks previously mapped under the name Shublik throughout the western Brooks Range, and this convention will be used in this report. As most recently defined in Mayfield and others (1983), most of the otuk formation is Triassic in age, with the uppermost portion ranging into the Jurassic. The Siksikpuk formation is mostly Permian age, with the lowermost portion of the unit ranging into the Pennsylvanian (?). Detailed fossil evidence is not given by Mayfield, and ages other than Permo-Triassic (Campbel1, 1967) are undocumented.

The Siksikpuk formation is conformable with the underlying Kuna Shale and Tupik Limestone of the Lisburne Group. At its upper contact, the siksikpuk is conformable with and gradational to the overlying otuk. The unit is approximately 400 feet thick and consists of thin to medium bedded dark gray to red, green and maroon chert, siliceous mudstone and shale, with minor silt. Very fine-grained sand was reported as a minor component by Campbell (1967), but was not seen in the field. The siliceous components are dominant in the siksikpuk. Where the unit is poorly exposed in the interior portions of the Lisburne Peninsula, it forms resistant ridges and knobs. Interbeds of nonsiliceous dark gray fissile to blocky black shale are nonresistant and generally covered away from the coast and deep stream cuts. Overall the unit is highly weathered and oxidized, and fresh samples were difficult to obtain. The siksikpuk was collected for age control, facies information and source rock potential. 
The contact between the otuk formation and the Siksikpuk is difficult to define without paleontologic information. The otuk unit is less siliceous than the underlying Permian section, and consists of shale, limestone, chert and siliceous mudstone. Total thickness of the otuk is approximately 200 feet. The lower part of the section contains thin-to medium-bedded shale, siliceous mudstone and some cherty limestone. Towards the top of the formation fossiliferous, dark lime mudstone becomes more abundant and is interbedded with chert and nonsiliceous soft black shale. The upper sequence also contains a distinctive rust to orange weathering pelecypod bed. Shales within the section are fissile to blocky, nonresistant and deeply weathered, and fresh samples were difficult to obtain. The otuk was sampled for age, facies and source rock information.

The Permo-Triassic Siksikpuk and otuk formations were deposited in the distal part of the Ellesmerian marine basin, and represent the basinal equivalent to the coarse clastics of the Sadlerochit Group to the north. These rocks were deposited in a quiet marine environment where siliciclastic deposition alternated with periods of nonsiliceous shale and limestone deposition, in response to changing oceanic conditions. Information on the source rock character in the nonsiliceous shales, representing a distal condensed zone, may help us interpret the source rock character of the Shublik buried beneath the Colville Basin to the north.

\section{Pennsylvanian section}

Mayfield, Tallieur and Ellersieck's (1983) stratigraphic column for the Lisburne Hills shows two units of Pennsylvanian (?) age (Enclosure 1). A 50-foot thick, black, carbonaceous shale conformably overlies Mississippian limestone beds of the Tupik formation (Lisburne Group). This unit is, in turn, conformably overlain by shales and cherts of the siksikpuk formation. Allochthonous Pennsylvanian Kuna and Siksikpuk shales, cherts and limestone have been correlated with the Lisburne Hills sequence (Mayfield, Curtis, Ellersieck and Taillieur, 1982 and 1983; Curtis and others, 1982 and 1983; and Ellersieck and others, 1982 and 1983). Previous work in the Lisburne Peninsula did not recognize Pennsylvanian rocks. The Pennsylvanian shale and chert represent a facies change from age-equivalent Lisburne carbonates deposited to the north to more distal basin siliciclastic deposition. The Kuna formation was not recognized in the field, and the lower part of the Siksikpuk formation, where observed, was badly weathered and highly siliceous.

\section{Upper Mississippian Lisburne Group}

The Lisburne Group is subdivided into three formations by Campbell (1967). These are, from oldest to youngest, the Nasorak, Kogruk and Tupik formations. The Nasorak formation consists of 65 feet of dark gray to black silty claystone, which is conformable with the underlying Endicott Group. Above this is a 25-foot thick section of thickly bedded, light gray, crinoidal packstone and wackestone. The upper member of the Nasorak is a rhythmically interbedded limestone and silty, calcareous shale sequence nearly 2,000 feet thick.

The overlying Kogruk formation is dominantly a dolomitic sequence with virtually no terrigenous content. Chert nodules are common and occur throughout the unit. This formation has a total stratigraphic thickness of 3,670 feet measured in the seacliffs on the south shore of Cape Lisburne. No visual porosity was observed in outcrop. Numerous samples were taken for porosity and permeability analysis to determine if micro-porosity is developed in the dolomites. 
Overlying the Kogruk is the Tupik formation which consists of interbedded carbonate mudstone, dark gray to black chert and very finely crystalline dolomite. Total thickness for this unit is estimated to be 500 feet.

\section{Lower Mississippian Endicott Formation}

A sequence of poorly exposed, marginal marine to nonmarine mudstones, sandstones and limestones were examined briefly during this field season. The sequence has been dated as Lower Mississippian by Campbell (1967) and is thought to be equivalent to the Endicott Group. Total thickness of this section is reported to be about 400 feet but poor exposure and possible structural complexity made it difficult to determine an accurate stratigraphic succession. The contact with the overlying Lisburne Group is reported to be conformable and gradational by Campbell (1967), however, field observations failed to confirm this. At all locations examined, the contact was either poorly exposed or demonstrably a fault contact.

\section{Silurian/Ordovician Iviagik Group}

Rocks of Silurian and Ordovician age outcrop in a 15-mile belt along the western coast of the Lisburne Peninsula. All of the coastline in this area belongs to the Tigara Village Corporation and permits are required for access. These rocks have been named the Iviagik Group (Martin, 1970) and are extremely well exposed in massive coastal cliffs. The early Paleozoic age of this formation was suggested by Tailleur (1972) on the basis of interpretation of an unconformable relationship between the Iviagik and overlying early Mississippian Endicott clastic section and a $435+/-13$ my $\mathrm{K} / \mathrm{Ar}$ date on mica taken from the unit. More detailed study by the USGS later confirmed an Ordovician to late early Silurian age with graptolite faunas found at locations 2.7 to $3.2 \mathrm{~km}$ and $10 \mathrm{~km}$ south of Cape Dyer (Grantz, Tailleur and Carter, 1983).

Several sections of the Iviagik Group were examined along the coast. In the contact area with the Endicott Group (immediately north of Iviagik Mountain, T9S-R60W), a thick, black carbonaceous shale separates a coarse graywacke facies of the Iviagik from rocks belonging to the Mississippian coal-bearing section. This shale unit is at the approximate location where Grantz and others (1983) recovered the Lower Paleozoic graptolites and is questionably assigned to the Silurian/Ordovician (see Photo 10, Appendix IV). The contact between the shale and Endicott appears to be a sheared unconformity, and represents the regional unconformity between the Franklinian and Ellesmerian sequences of Arctic Alaska.

The Iviagik Group consists of light to dark gray weathering graywacke, mudstone, slate, phylite and shale. The unit is mildly metamorphosed, structurally disturbed and highly indurated. The northern part of the section contains medium-to thick-bedded, fine to coarse grained, micaceous, siliceous graywacke and interbedded mudstone. On the north part of Iviagik Mountain (33-9S-61W), a conglomeratic olistostrome sequence is exposed. Southward along the coast, the unit becomes more thinly bedded and finer-grained. Here slates, phyllites, and siliceous mudstones are the dominant lithology with fine-grained graywackes subordinate. In one location, the dark rocks are cut by a massive calcite vein, some 30 feet thick and over 1,000 feet long (see Photo 7, Appendix IV). The total thickness and complete age range of the unit is uncertain, as its base is not exposed and no detailed sections have been measured. The diagenetic and thermal effects which 
the Iviagik has undergone preclude any potential for hydrocarbon source or reservoir.

The fine to coarse clastics of the Iviagik Group represent a distal marine turbidite flysch sequence deposited from rapidly eroding highlands presumably related to an early Paleozoic subductive margin. This sequence correlates in age and depositional character with the regional Franklinian "Argillite" which forms the economic basement across the North slope. The similarity of the Iviagik to that of the North slope authochthon basement, along with the similarity of the Lisburne Hills Ellesmerian to that of the palinspastically restored northernmost thrust plate of the western Brooks Range, has led Mayfield, Tailleur and Ellersieck (1983) to conclude that the rocks of the Lisburne Peninsula thrust sheets were originally deposited in the northern part of the Ellesmerian seaway, relatively close to the chukchi sea (see Enclosures 3 and 7 ).

\section{Western De Long Mountains Stratigraphy}

Lower Cretaceous Opikruak Formation

The lower Cretaceous opikruak formation represents the initial turbidite flysch sequence which was deposited in the foredeep on the north side of the ancestral Brooks Range during the Brookian Orogeny. The following description is taken largely from Ellersieck, Curtis, Mayfield and Tailleur (1983), who mapped the unit in the De Long and Misheguk Mountains. The opikruak consists of graywacke and shale, with occasional conglomerate layers and olistolith sequences. Features characteristic of turbidity currents, such as rhythmic layering, ripple marks, tool marks and fining upward sequences are common. Conglomerate clasts are composed of chert from the otuk and siksikpuk formations, limestone and chert from the Lisburne Group, arkose from the Nuka formation, limestone from the Baird Group and some gabbro or diabase of uncertain origin. The base of the opikruak is generally an unconformity, although there may have been continuous deposition in northern areas where it sits on the Ipewik formation. The unit ranges in thickness from a few hundred meters to over 1,000 meters, and is present in allochthons one through five. Fossil evidence from pelecypods shows that the base of the sequence is older in structurally higher thrust sheets, supporting the concept of a northward prograding flysch deposit. Ages at the base of the unit as old as Tithonian (latest Jurassic) are documented from the highest thrust sheet (southernmost depositional package) and as young as Valanginian (middle Neocomian, early Cretaceous) from the lowest thrust sheet (northernmost depositional package). Equivalent rocks in the Lisburne Hills area (Ogotoruk, Telavirak and Kisimolok formation?) reach 5,000 meters in thickness, although their total age range is not well documented.

The Opikruak formation was visited at several locations in the western De Long Mountains by the 1986 field party (Stops 7-23-2, 5, 6, 11 on Enclosure 9). Lithologically, the unit is very similar to the lower cretaceous turbidites seen in the Lisburne Hills. Silty sandstone beds, typically ranging from three to eight inches thick, were collected for thin section study. Carbonaceous to silty black and gray shales were collected for age control and source rock analysis. It is doubtful that sandstone units of the late Jurassic to early Cretaceous turbidite flysch sequence were deposited as far north as the central chukchi sea. The only reservoir potential this package may have would be for the southernmost part of the OCS 109 sale area. Shales of equivalent age within the main part of the Chukchi sea and western NPRA 
should correlate more in character with the Upper Kingak and Pebble Shales, than with the opikruak shales coming off the rising Brooks Range.

\section{Jurassic to Lower Cretaceous Ipewik Formation}

As discussed above, the Ipewik formation is an upper Jurassic to lower Cretaceous (Neocomian) unit present in the northern thrust sheets of western Brooks Range (Crane and Wiggins, 1976; Ellersieck and others, 1983). The formation consists of gray and maroon shale, some papery carbonaceous shale, siltstone, coquinoid limestone, and sandstone. The shale facies locally contains sparse well-rounded pebbles of quartz, chert, gabbro and granite. In Ellersieck's thrust sheet one (Enclosure 2), there are local occurrences of a distinct Neocomian (Valangian) pelecypod coquina and a clean, well sorted quartz sandstone (Tingmerkpuk Member) interbedded with shales. The sandstone is described as massive to thickbedded, fine-to medium-grained and ranges from 0 to 50 meters in thickness. Ellersieck suggests this sandstone may indicate a shoaling event during the Neocomian. The presence of a clean quartz sand in this area is enigmatic and more information on the unit will be sought by personal communication with the authors at the UsGs.

The Ipewik unit as a whole correlates regionally with the uppermost Kingak formation and the Pebble Shale to the north and the okpikruak formation to the south. It represents deposition in a relatively stable portion of the basin, north of the area of turbidite flysch sedimentation. The basal contact appears to be conformable on the otuk formation.

The Ipewik shale is very poorly exposed in the westernmost De Long Mountains area visited by the field party. Several samples of black carbonaceous shale were collected for age and source rock analysis (Stops 7-23-5, 12 on Enclosure 9). The pelecypod and sandstone facies described above occur further to the east, outside of the area covered in 1986.

\section{Pennsylvanian-Jurassic Otuk/Siksikpuk Formations}

The otuk and Siksikpuk formations of the Etivluk Group were studied in Allochthons one and Two of Mayfield and other (1983) in the western De Long Mountains (see Enclosure 2). The group is 300 to 320 feet thick in this area and, according to Mayfield, ranges in age from Pennsylvanian to Jurassic. The otuk is conformably overlain by the Jurassic to lower Cretaceous Ipewik formation and the siksikpuk rests conformably on the Kuna formation of the Lisburne Group. The Etivluk Group consists of interbedded gray, maroon and green chert and gray, green and black shale and siliceous mudstone. Some orange to brown weathering silty, black, fetid, micritic limestone beds, ranging up to eight feet in thickness, were found interbedded in a black shale section of the otuk formation at spiney Ridge. The lower (Permian?) portion of the group is highly siliceous, containing abundant chert and siliceous mudstones. The younger (Triassic to Jurassic?) section contains a higher proportion of nonsiliceous shale and occasional siltstone to (?) very fine-grained sandstone. Both the otuk and Siksikpuk were often found to be highly weathered and sometimes appeared to be mildly metamorphosed. Samples of nonsiliceous shale and the fetid black limestone were collected for source rock and thermal maturity analysis and age control (Stops $7-23-1,3,5,6,8$, 10 on Enclosure 9). 


\section{Potential Reservoir Facies}

The potential for reservoir development within the allocthonous Ellesmerian sequence is very low due to the distal depositional environment of the Permian through Jurassic rocks. This section is characterized by highly siliceous shales and siltstones with interbedded cherts. Reservoir potential within the carbonate dominated Lisburne Group is also poor due to the degree of cementation and diagenesis observed in outcrop. The Lower Ellesmerian Endicott Group is also considered to be nonreservoir based on lack of observed porosity in outcrop.

\section{Potential Source Rock Facies}

Potential hydrocarbon source rocks are present in both the Ellesmerian and Brookian sequences in the western Brooks Range. The advanced level of thermal maturity of these units is the result of structural burial by Brookian thrust sheets, as well as depositional burial, and will not provide a direct correlation with the burial history of equivalent source rocks beneath the Colville Trough or Chukchi Sea. The heightened thermal maturity and pervasive deep weathering is expected to hinder geochemical evaluation of the samples collected.

Facies expected to have amorphous oil-generating kerogen include:

$\begin{aligned} \text { Jurassic Ipewik Formation - } & \text { marine black shale facies, } \\ & \text { Peble shale equivalent, } \\ & \text { ? condensed zone. }\end{aligned}$

Permo-Triassic otuk/ Siksikpuk Formations -

Mississippian Lisburne Group - chert and shale distal marine facies, ? condensed zone, Sadlerochit Group equivalent.

Marine black shale interbedded with carbonates, limited thickness, limited volumetric potential.

Facies expected to have structured gas-generating kerogen include:

$\begin{array}{ll}\text { Mississippian Endicott } & -\quad \begin{array}{l}\text { coal and plant bearing } \\ \text { nonmarine to marginal marine } \\ \text { shale facies. }\end{array} \\ \text { Brookian turbidites }- & \text { includes ogotoruk, Telavirik, } \\ & \begin{array}{l}\text { Kisimolok, Fortress Mountain } \\ \text { and Okpikruak formations, }\end{array} \\ & \text { structured kerogen expected } \\ & \text { on basis of previous Fortress } \\ & \text { Mountain analyses to north. }\end{array}$

Source rock analyses for richness (TOC) and kerogen type (oil vs. gas) will be integrated into palinspastically reconstructed facies maps of the western North Slope, and merged with well control data to the north. This reconstruction of source facies and quality will provide framework constraints for SUBSIDE basin modelling of the source rock potential of the Chukchi sea/Western NPRA. GCMS oil typing of rich source facies will provide additional information for our regional understanding of oil generation across the North slope.

Sample Analysis Schedule

Sample locations are recorded on USGS topographic base map (Enclosures 8 to 25). All source rock samples collected from the Lisburne Hills and De Long Mountains were sent to Brown and Ruth Laboratories, Englewood, Colorado, for analysis 
(see Appendix III, Sample Register, Source Rock Samples). Source richness (total organic carbon) is scheduled to be run on all 57 samples. Rock eval pyrolysis will then be run on all rocks with greater than 0.5 percent TOC. Upon evaluation of the results of these tests, additional work may be done by Brown and Ruth (Visual Kerogen, TAI, Vitrinite, etc.) or by Amoco's Tulsa Research Lab (GCMS source rock typing).

Paleontologic samples range in age from ordovician to early Cretaceous and are being evaluated by the Denver Region Paleontology staff (see Appendix III, Sample Register, Paleo Samples ).

Lithologic samples of potential reservoir rocks, including sandstone facies from the Early Cretaceous turbidite section and Early Mississippian Endicott Group and dolomite and limestone facies from the Mississippian Lisburne Group, will be sent out for thin section preparation and petrographic study (see Appendix III, Sample Register, Lithology Samples).

\section{Field Conditions and Logistical Support}

Field work was conducted out of the village of Point Hope. The field party stayed at the Whaler's Inn, a small hotel which provided lodging and meals for $\$ 150 / \mathrm{man} /$ day. The hotel provided adequate support and its facilities include showers, washer/dryer, public telephone and satellite television. No other accommodations are publicly available within the Point Hope village. During our stay, the hotel was crowded by a large construction crew, working for the village Tigara Corporation, and a National Guard company. At present, the hotel has eight two-person rooms, with any overflow assigned to the "old camp" building, a dormitory style bunkhouse. The Whaler's Inn is owned and operated by the Tigara Corporation, and no matter what is stated beforehand, reservations are never guaranteed. The only other possible locations for a camp are at the Cape Lisburne DEW Line station, or at a remote location on other than native lands in the Lisburne Hills. The costs and logistics for these alternatives were not researched by the 1986 field party. Exxon, who was also working in the area, stated that a commercial camp (such as set up by Production services, Inc.) on the DEW Line site was unreasonably expensive as compared to staying in Point Hope. For work exclusively in the De Long Mountains, arrangements may be made to stay at the Red Dog Mine, run by Cominco.

Amoco's field crew was supported by an ERA Helicopters, Inc. 206 B Jet Ranger (Pilot - Len Paur, Mechanic - Ken Vickers). Transport of personnel to the Point Hope area was made through Kotzebue on daily flights available on Alaska Air and its affiliate, Bering Air. Ryan Air also currently has daily flight service between Kotzebue and Point Hope. As jet fuel is not commercially available at point Hope, arrangements were made with ERA to fly nineteen 55-gallon drums to the airstrip on the weekly freight flight on Northern Air Cargo (Anchorage to Point Hope). Once a week freight service, available on Mark Air, was used to ship samples down to Anchorage. The only other refueling site available at present is at the Red Dog Mine, and requires prior permission if at all possible.

Lands within the Lisburne Peninsula area include state selected, Arctic Slope Regional Corporation selected, Tigara Corporation Village selected, Alaska Marine National Wildlife Refuge selected and miscellaneous native allotments. Permits, with varying stipulations, were obtained from all of the respective land owners, and are included in Appendix II. The individual land owners for the native allotment lands are 
virtually impossible for our land department to contact, and we were advised to avoid these areas if possible to prevent potential trespass. The only permit access fees required were paid to the Tigara Village Corporation, for two days of work at the rate of $\$ 1,000$ per day.

In the western portion of the De Long Mountains visited by the field party, all lands were either Regional Corporation selected, for which permits were obtained, or within the Noatak National Preserve/Noatak Wilderness, where all entry is prohibited.

Filing of a variety of geological reports was required as part of the permit stipulations from the Tigara Village Corporation, Arctic Slope Regional Corporation, Bureau of Land Management, and Alaska Marine National Wildlife Refuge. Information concerning these reports is included as Appendix $V$.

Weather conditions during late July in the Lisburne Peninsula area included a temperature range from the low $40^{\prime} \mathrm{s}$ to the high $60^{\prime} \mathrm{s}$. Typical days were overcast, with periodic light rain or fog. Although fog conditions made traversing the interior portion of the Lisburne Hills difficult, no down time due to weather was recorded. The major coastal cliff exposures are accessible in all but the heaviest fog. Typical Brooks Range and coastal plain wildlife is present in the area. A rifle is considered essential equipment for protection against the grizzly bear population for all work away from the helicopter. The southern coastal cliffs from Cape Thompson to the chariot site are a major nesting area for a variety of birds, including sea gulls, puffin and murres. Helicopter navigation in these areas in hazardous due to the density of birds in the flight path, and the AMNWR permit requires that flight closer than $1 / 2$ mile from the seabird nesting sites be avoided.

\section{Tectosat Program}

Tectosat, Inc., an England based firm, is preparing a combined remote sensing/structural field study for northern Alaska. Amoco has subscribed to this program, which is scheduled to be completed in 1987. Two Tectosat geologists, Wim Kampschuur and Hank Bakker, were in the Lisburne Peninsula area during our stay, and were provided with helicopter support to several remote field camp locations. Signed releases were required for each flight. It is hoped that their detailed structural study of the northern, western and southern cliff exposures will determine if the Silurian/Ordovician rocks have undergone multiple deformational events and what the relationship is between the north-trending structures of the Lisburne Peninsula and the east-west trending structures of the western Brooks Range.

\section{Industry surveillance}

Only two other oil firms had field parties in the Lisburne Peninsula area during our field season - Exxon and Shell. Exxon ran a month-long program which consisted primarily of mobile coring operations to obtain fresh samples from more complete sections. The core rig was commercially contracted, and operated off of a VW engine for the actual coring and two pumps which drew water from a nearby stream. The operation is continuous, using a 1 3/8-inch diameter core, and under normal conditions does not result in any cuttings to dispose of. Location of the core site is limited to within 500 yards (?) of a water supply. Depth rating for the coring rig and the depth to which Exxon was typically coring is not known. Each core location took 1 to 2 days to drill. The coring rig was 
transported by helicopter (an ERA A-Star), and required seven trips to move all of the equipment, including engines, pumps, hose, pipe and lumber. Two core sites discovered by Amoco in the field are plotted on Enclosure 8, and were located in areas of Permo-Triassic exposure. The intent of Exson's program is thought to be to collect fresh samples of the Permo-Triassic, (?) Jurassic and Lower Cretaceous for source rock and paleo analysis, as well as Lisburne carbonate and Lower Cretaceous sandstone samples for reservoir study. Exxon stated that they had used this portable coring rig for several seasons and, although it is expensive, it is very valuable, especially in areas of poor exposure and deep weathering. Photographs of the rig set up for coring are included in Appendix IV. Like Amoco, Exxon was working out of the Whaler's Inn Hotel in Point Hope. Their operations were exclusively in the Lisburne Peninsula area, and their field party did not visit the De Long Mountains to our knowledge. Shell's field party only spent a few days in the Lisburne Peninsula area and did not stay in Point Hope. Reportedly, they were camped for a short time at a private home or lodge south of the area on the Wulik River. Their ERA Long Ranger helicopter was sited working along the southern and western coastal cliff exposures. During return transport of our helicopter, Shell's crew was sited along the coast between Point Lay and Barrow, possibly scouting for oil seeps. 